\title{
Waqf Productive Efficiency: Evidence from Yayasan Badan Wakaf Sultan Agung, Semarang
}

\author{
Tika Widiastuti \\ Islamic Economics Department, \\ Universitas Airlangga \\ Surabaya, Indonesia \\ tika.widiastuti@feb.unair.ac.id
}

\author{
Wahyuningsih \\ Middle East and Islamic Study, PostGraduate \\ School, \\ Universitas Indonesia \\ Jakarta, Indonesia \\ Wahyuningsihayu75@gmail.com
}

\begin{abstract}
This research is aimed to gain understanding of the influence of production factors, namely, capital, workforce and waqf assets, on the output (revenues) of waqf assets' productivity by using the CobbDouglas production function. The research object is focused on Yayasan Badan Wakaf Sultan Agung (YBWSA) Semarang, which has been serving in managing waqf assets productively in the education and healthcare sectors since 1950. This research used primary data from interview and secondary data from monthly financial statements in the 2010-2012 period.

This research was conducted using quantitative analysis technique through a double linear regression model modified from the Cobb-Douglas function equation. Furthermore, in order to obtain inter-variable partial and simultaneous correlation, $t$-test and $F$-test were conducted. Tests result show that production factors, partially and simultaneously, have insignificant correlation to output (revenues) of waqf assets. On the other hand, output production scale of YBWSA is classified as decreasing return to scale.
\end{abstract}

Key Words: Cobb-Douglas, Production function, Productive Waqf, YBWSA.

\section{INTRODUCTION}

Waqf is a social instrument that could be an effective strategy for poverty alleviation and reducing unemployment. According to Wibisono (2011:111), waqf is a unique instrument based on three elements: virtue (birr), kindness (ihsan) and brotherhood (ukhuwah). Therefore, waqf is not only an instrument for worshiping Allah, but also an instrument to help others. Many facts show that some institutions could withstand using waqf funds and even give a significant contribution.

In Indonesia, waqf is a potential instrument and keeps growing year by year. According to data from Sistem Informasi Wakaf (SIWAK - Waqf Information System) from the Ministry of Religious Affairs, currently there are 47,806.11 hectares of land waqf spread in 318,769 locations in Indonesia. Most of them are used for religious and social purposes such as mosques and small prayer sites $(73.5 \%)$, schools $(10.44 \%)$, graveyards $(4.68 \%)$ and pesantrens $(3.04 \%)$ (SIWAK Kemenag, 2017).

The aforementioned data confirm conditions in the field that many of the waqf lands are used merely for non-productive purposes, and just a few are utilized for productive purposes. The nazir - who manage waqf assets - don't make significant efforts to manage waqf land. Thus, the benefit of waqf has not yet improved the life of society. This condition isa paradox with the current waqf regulation, the waqf Act No. 41/2004, which t encourages productive waqf (Hilmi, 2012:125). The development of productive waqf is seen as an important part of the development of Islamic economics to improve people's livelihood. Therefore, waqf productivity should be increased to achieve these goals. In line with the government policy in the Waqf Act, UU No. 41/2004, the increase in waqf productivity is one of the main things required in order to tackle problems such as poverty, education, health, unemployment and economic empowerment.

Despite being legally supported, there are some constraints that inhibit management of productive waqf assets. According to Ishom (2014:690), these constraints are: (a) waqf management is still conducted in traditional ways; (b) many people don't yet understand form of productive waqf; (c) lack of promotion to society concerning cash waqf; and (d) lack of competence and professionalism by the nazir in order to manage waqf for productive purposes.

Focusing on the management and professionalism of nazir, although productive waqf has been encouraged by regulation, productivity of waqf assets is the main problem in managing waqf. Most nazirs work to operate waqf assets as a side job only (Huda et al., 2017:48). This is a paradox because, in fact, the government gives huge support, such as additional funds to operate waqf assets channeled by 
the Ministry of Religious Affairs from 2005-2013 amounting to IDR 56.9 billion. However, waqf productivity has not been well-optimized (Arifin, 2015:668).

Lack of literature is also found on waqf productivity topics. A closely related topic with waqf productivity is performance of non-profit organizations, such as Martinez Franco and Raja (2016) in the case of the Spanish foundation sector, while Huang and Chen (2012) studied Non-Profit Organizations (NPOs) performance with qualitative data envelopment analysis. Lastly, a study from Berber et al. (2011) analyzed NPOs performance in the US with two-stage data envelopment analysis.

On waqf discourses, however, most studies were merely conducted on the theological or legal aspect of waqf (Fauzia, 2008) and quantitatively researched. Empirical analysis on waqf performance and productivity is important in order to assess and improve productive waqf management in Indonesia. Initialization of such research will contribute to the betterment of waqf institutions.

This paper aims to fill the aforementioned research gap by looking in depth at how much influence inputs of waqf asset have on output in a waqf institution. Also, this paper tries to provide a solution and pioneers discourse on the issue of waqf assets productivity.

\section{A. Waqf and Productive Waqf}

The word waqf is taken from the Arabic verb "waqafa", which means standing still or pausing. They have the common meaning of the word "habs", which means lock or hold. According to Lopez et al. (2010: 4), the Prophet (peace be upon him) also uses the word al-habs (holding) in terms of holding a treasure whose benefits are used for virtue and religion. Waqf (plural: Awqaf) or habs (plural: hubus) have long been used in the history of the Arab world, especially for Muslims to describe an act of generosity through charity, which is called al-shadaqatu jariyyah or giving that has continuous benefit.

As mentioned earlier,most waqf assets are utilized for non-productive purposes in the traditional way of management. With the emergence of the current issue on productive waqf, it is important to define the role of waqf assets utilization for the economy. Waqf assets that are managed for productive purpose can be considered a part of a unit investment. Investment is the main foundation for economic development and has the meaning of directing the majority of the property owned by a person to form the production of capital, which is then able to produce goods and services and can be used for generations to come.
Therefore, the result of waqf asset, as stated by Danardono (2008: 14), can be divided into two parts, namely: (a) Direct waqf, which is waqf property that produce services in the form of goods to be consumed directly by the person entitled to the waqf property, such as houses, hospitals, schools, foundations, settlements, and others; and (b) productive waqf, which is managed for investment purposes and the production of goods and services that are allowed under Islamic law. Waqf in this form means the capital is invested, then the investment returns are distributed to the entities that qualify.

According to Kahf (2005: 67-70), there are several requirements that must be fulfilled to establish waqf to become productive assets:

1. The need for a legal framework that provides a clear definition of waqf institutions and organizations, describes the function and purpose of waqf, social rules and regulations regarding the economy and the protection of waqf assets.

2. The need for profound changes to the management of waqf, in particular the form of waqf investment, in order to meet two objectives, namely, (i) to increase the efficiency and productivity of waqf assets; and (ii) to minimize the practice of fraud and corruption by a waqf manager (nazir).

3. The need to form waqf networks that can promote the development of waqf and offer the waqf to generous people.

4. The need for technical support, managerial and funding (capital) on the management of waqf to improve the productivity of waqf assets.

5. The need for a master plan or strategic plan in each region to deploy waqf assets to maximize benefits and services.

Management of productive waqf is necessary in order for the purpose and benefits of the waqf asset to be produced optimally. Waqf management, according to Hakim (2010: 24), provides guidance and services to a number of properties devoted to realize the goals and efforts and should be concentrated on the effort to realize the benefits of the acquisition for the purposes specified in the waqf property. Good waqf management will also lead to continous benefits and sustainable income for waqf institutions (Mutalib and Maamor, 2016:36).

\section{B. Production}

Production in a simple term which, according to Ginting (2007: 1), entails the entire process and the operations performed to produce a product or service. The production system is a collection of subsystems that interact with the aim of transforming inputs into 
outputs production. Production input may include raw materials, machinery, labor, capital and information. The production output is a product that is produced and the following side, such as like sewage, information, and so on.

Definition of production in an Islamic perspective is, according to Duaib (1998: 54), an attempt to exploit the resources in order to produce economic benefits. The word "production" in Islamic economics is one of the most important keywords. From the concept and the idea of production it is emphasized that the primary objective to be achieved in economic activity is the balancing of benefit (maslahah) for the individual and the benefit (maslahah) for society.

In a production process, a company needs production input, which, in the micro-economic theory, is often referred to as factors of production (Pindyc and Rubinfield, 2007: 211). In terms of economics, Nasution (2006: 111) classified the factors of production into capital (including land, buildings, machinery and inventory or supplies), materials (raw materials) and labor (human). The main factors of production in Islam are natural resources and labor,

The purpose of production is to fulfill human needs and the ability to produce is limited by the availability of the factors of production required. Hidayat (2010: 222) states that the success of the production is located in the use of factors of production that are able to produce goods or services with as high a quality as possible.

\section{Productivity}

An understanding of the concept of productivity is very different from the concept of production, although it is very closely related. The production is one component of business productivity, in addition to the quality and output. Production is a process or activity related to the output and generally expressed by production volume, while productivity is related to the efficient use of resources (input) expressed in a comparison (ratio) of output and input.

At the macro level, the concept of productivity is very important, especially because the concept is a matter of economic growth. Discussion of productivity by Widayati (2010: 42) is often associated with the topic of the sources of economic growth. Economic growth itself is an indicator in measuring the performance of an economy and macro productivity is an aggregation of micro scale at the enterprise level.

In general, productivity is simply defined as the ratio between output and input over a certain period. Measures of productivity is a concept that is often encountered. However, this concept has evolved with the introduction of the concept of the production function by Charles Cobb and Paul Douglas who use inputs of capital and labor in the form of an equation to estimate parameters. (Widayati, 2010: 45).

\section{Cobb-Douglas Production Function}

The Cobb-Douglas production function that is often used by researchers and this functionality was first introduced by Cobb and Douglas in 1928 and has been accepted as an effective formula in determining a production model (Hanif and Arshed, 2016:294).

The definition of the Cobb-Douglas production function as proposed Soekartawi (1990: 160) is a function or equation that involves two or more variables with one variable called the dependent variable (Y), which describes, and the other the independent variable $(\mathrm{X})$, which explains. Completion of the relationship between $\mathrm{Y}$ and $\mathrm{X}$ is usually by regression; the variation of $\mathrm{Y}$ will be affected by the variation of $\mathrm{X}$. Therefore, the rules on the regression line also apply to the completion of the Cobb-Douglas function.

There are several requirements that must be met in order to use the Cobb-Douglas production function. These requirements are: (a) no observation explanatory variable (X) is equal to zero; (b) assuming there are no differences at each observation technology in the production function. If the CobbDouglas production function is used as a model of observation and, if necessary, analysis requires more than one single model, the difference in the models lies not on the intercept and slope of the line of the model; (c) each of the variable $\mathrm{X}$ are the perfect competition; (d) there is only one variable that is described (Y); (e) the difference in location is included in the error factor.

According to Rahman and Mamun (2017:4), the Cobb-Douglas production function can be written mathematically as follows:

$Q=A \cdot L^{\propto} \cdot K^{\beta} \cdot e^{u}$

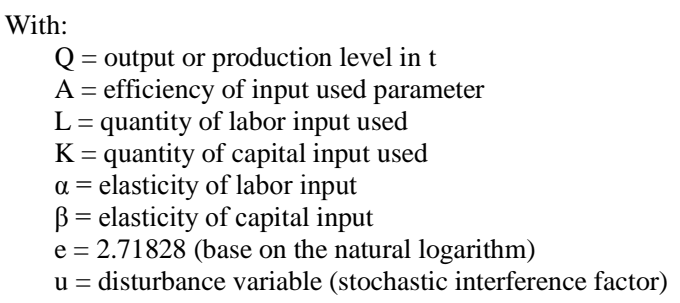

The way to obtain the Cobb-Douglas production function is to create a logarithmic linear equation (of the Cobb-Douglas production function) thus becomes: $\log Q=\log A+\propto \log L+\beta \log K+v$

$Q *=A *+\propto L *+\beta K *+v *$ 
Many economists consider the Cobb-Douglas production function as a good approach of how the actual economy turns capital and labor into goods and services (Pindyc and Rubinfield, 2007: 288). By doing regression in the equation above efficiency parameters (A) and the elasticity of its inputs will be easily obtained. One of the advantages of the Cobb-Douglas production function is that it can easily can create linear equations. Among the various kinds of analysis that can be built from the Cobb-Douglas production function is input elasticity, return to scale and efficiency. Also, the Cobb-Douglas production function is a common mathematical function to show a set of production possibilities (Mehrabani, 2016:10).

Input elasticity is the percentage of output change as a result the percentage of input change. Elasticity of capital input (K) and the elasticity of labor input $(\mathrm{L})$ are obtained through:

Elasticity $\mathrm{L}=(\mathrm{dQ} / \mathrm{Q}) /(\mathrm{dL} / \mathrm{L})=(\mathrm{dQ} / \mathrm{dL}) .(\mathrm{L} / \mathrm{Q})=\alpha \ldots \ldots \ldots \ldots \ldots \ldots \ldots . .(4)$

Elasticity $\mathrm{K}=(\mathrm{dQ} / \mathrm{Q}) /(\mathrm{dK} / \mathrm{K})=(\mathrm{dQ} / \mathrm{dK}) .(\mathrm{K} / \mathrm{Q})=\beta \ldots \ldots \ldots \ldots \ldots \ldots . . .(5)$

Based on the equation above, it can be explained that the regression coefficient and the Cobb-Douglas production function are both input elasticity.

It is necessary to know Return to Scale (RTS) to determine whether the activities are investigated following the rules of increasing, constant, or decreasing return to scale. Return to scale is based on the sum of the elasticity of inputs $(\alpha+\beta)$, where:

1. If $\alpha+\beta>1$, it implies increasing return to scale. This means that each of the subsequent additional manpower will create additional production that is greater than previously, so that additional production due to additional average production of labor (APL) is also increased. This means that the welfare of workers also increases.

2. If $\alpha+\beta=1$, it implies constant return to scale. This means that the additional production generated by each additional labor (marginal product or MPL) declines, so that the additional overall production and increase of production average is slower than the stage of increasing return to scale. The boundary between this condition to the next condition is a level in the production process wherein average production is highest.

3. If $\alpha+\beta<1$, it implies decreasing return to scale. At this stage, the use of labor in the production process has been too excessive, so that additional labor productivity becomes negative. Labor surplus will lead to decreased average production of labor. As a result, the level of the prosperity of labor will decline.

Efficiency, according to Mankiw (2001: 153), is an ideal condition when a society can obtain the results or the maximum benefit from the use of all the resources scarcity. In the Cobb-Douglas function, efficiency coefficient values are identified by the intercept. A greater intercept coefficient indicates the company is more efficient.

\section{E. Waqf Productivity Framework}

The framework of the productive waqf productivity measurement model based on the CobbDouglas production function approach can be described as follows:

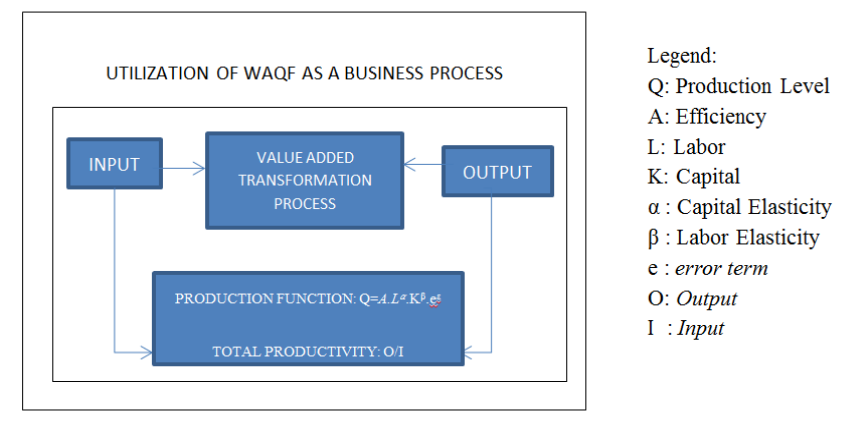

Fig. 1. Measurement Framework of Productivity with CobbDouglas Function Production

Source: Djalal and Nugroho, 2010.

\section{RESEARCH METHODOLOGY}

\section{A. Research Approach}

This paper uses descriptive method with quantitative approach, which aims to seek relationships and to explain the causes of changes in social facts which are measurable (Sukmadinata, 2006: 12-13). In context of this study, it is the relationship between input and output in a waqf institution.

Quantitative research has a series of steps or a standard procedure which is a tool for the researchers. This is a research method to reveal a clear picture of the effect of the use of factors of production (capital and labor) on the productivity of waqf assets in the institution of productive waqf based on the data obtained, by collecting and analyzing this data and turning it into new information.

\section{B. Research Object}

Yayasan Badan Wakaf Sultan Agung (YBWSA) in Semarang, Central Java is the object of this study. YBWSA is an Islamic foundation that focus on utilization of waqf assets in Semarang. It has several schools, a hospital (Rumah Sakit Islam Sultan Agung/RSISA), a university (Universitas Islam Sultan Agung/UNISSULA) and some business units. This foundation is chosen due to data availability and its diversity of operating fields. 


\section{Research Variables}

The variables to be tested in this study are:

1. The independent variables (exogenous variable) consist of capital (K), Labor (TK), and Waqf Assets (AW).

2. The dependent variable (endogenous variable) is output (Q) of productive waqf asset.

\section{Dataset}

Data used in this study are primary data and secondary data, which are time series data in the form of monthly data during a three-year period (20102012). An explanation of each of these data follows:

1. Primary data in this study were obtained through interviews with a nazir using a list of questions provided. The primary data required are the identity of the nazir, their income, the amount of labor in productive waqf, financial statements of the institution from the period 2010-2012, capital foundations, waqf assets, waqf output, institutional, organizational and institutional structures, and the other supported data.

2. Secondary data were obtained from official data in the form of financial statements issued by Yayasan Badan Wakaf Sultan Agung Semarang for a three-year period (2010-2012) consisting of monthly data.

\section{E. Analysis Technique}

This research uses multiple linear regression analysis model with OLS (Ordinary Least Square) or the least squares method using annual data, based on the analysis used, either partially ( $t$ test) or simultaneously (F test). By looking at the results of the analysis method, determinant coefficient (R2) and a partial determinant coefficient (R) can also be known.

Determinant coefficient (R2) and a partial determinant coefficient $(\mathrm{R})$ shows the ability of the independent variable to explain the dependent variable by using regression analysis, so it will obtain a simultaneous or correction which is proof of the hypothesis given. This study uses a mathematical method approach with the basic models of the CobbDouglas function.

Statistical formula used in this study is multiple linear regression. The relationship between the variables used is described in a function:

$\mathrm{Y}=\mathrm{f}(\mathrm{X})$

While the regression equation used is: $\log Q=\log A+\propto \log L+\beta \log A W+$

$\gamma \log K+v$

The ordinary least squares method (OLS) is used to obtain the value of each parameter. To get a good estimate by OWLS, then BLUE (Best Linear Unbiased Estimator) is applied in order to get classical assumptions, namely :

a. The relationship between $\mathrm{Y}$ (the dependent variable / exogenous) and $\mathrm{X}$ (independent variable / endogenous) is linear in the parameters.

b. The value of $\mathrm{X}$ remained for repeat observation (non-stochastic). Since the dependent variable is more than one, then it is assumed there is no linear relationship between the independent variable or no multicolinearity.

c. $E\left(e \mid X_{i}\right)=0$, meaning the expected value or the average of the variable interruptions $e_{i}$ is zero.

d. $\operatorname{var}\left(\mathrm{e}_{\mathrm{i}} \mid \mathrm{X}_{\mathrm{i}}\right)=\mathrm{E}\left[\mathrm{e}_{\mathrm{i}}-\mathrm{E}\left(\mathrm{e}_{\mathrm{i}}\right)\right] 2$ $=\mathrm{E}\left(\mathrm{e}_{\mathrm{i}} 2 \mid \mathrm{X}_{\mathrm{i}}\right)$

$=\sigma^{2}$

Meaning variants of the disturbance variables $\mathrm{e}_{\mathrm{i}}$ are the same (homokedastisitas)

e. $\operatorname{cov}\left(e_{i}, e_{j} \mid X_{i}, X_{j}\right)=E\left[e_{i}-E\left(e_{i} \mid X_{i}\right)\right]\left[e_{j}-E\right.$ $\left.\left(e_{j} \mid X_{j}\right)\right]$

$=E\left(e_{i} \mid X_{i}\right)\left(e_{j} \mid X_{j}\right)$

$=0$

Meaning there is no serial correlation between disturbance variables $\left(\mathrm{e}_{\mathrm{i}}\right)$ or disturbance variables $\left(\mathrm{e}_{\mathrm{i}}\right)$ not connected with other disturbance variable $\left(\mathrm{e}_{\mathrm{j}}\right)$ (Gujarati, 1998: 34-38).

The quantitative analysis used in this study uses econometric tools in SPSS 18 software.

\section{RESULTS AND ANALYSIS}

Productivity of waqf asset at Yayasan Badan Wakaf Sultan Agung, which is mostly in the form of services in education and health through elementary and secondary Education (DIKDASMEN), college (DIKTI), and Rumah Sakit Islam Sultan Agung (RSISA), which is the operational partially supported by several businesses with the aim to generate profit that is utilized for the development of education and health.

In connection with services produced by YBWSA, this research shows the output services, capital and waqf asset stated in the report of monthly income and the amount of labor used in support of the operational aspects of waqf asset productivity on YBWSA for the period 2010 to 2012. 


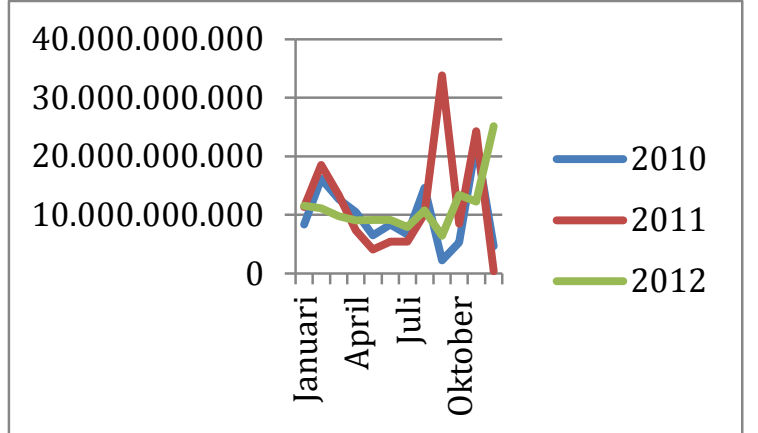

Fig. 2. Output (Income) Growth at YBWSA period 2010 - 2012 Source: YBWSA Financial Report period 2010 - 2012

From Figure 2, there is a significant increase and a decrease (fluctuation) of output (income) from management of waqf assets, mostly from the education and health sectors. The highest output that can be achieved by YBWSA between 2010 and 2012 occurred in September 2011, which reached 33.8 billion. And, based on the same data, the lowest output achieved by YBWSA occurred in December of 2011, which amounted to 405 million. Significant fluctuations of income occurred in 2010 to 2011. Meanwhile, in 2012, the revenue fluctuations tend to be stable. The increase and decrease in output is caused by the condition of new admissions or students who have graduated to the education sector and also a number of patients that are handled by the RSI-SA.

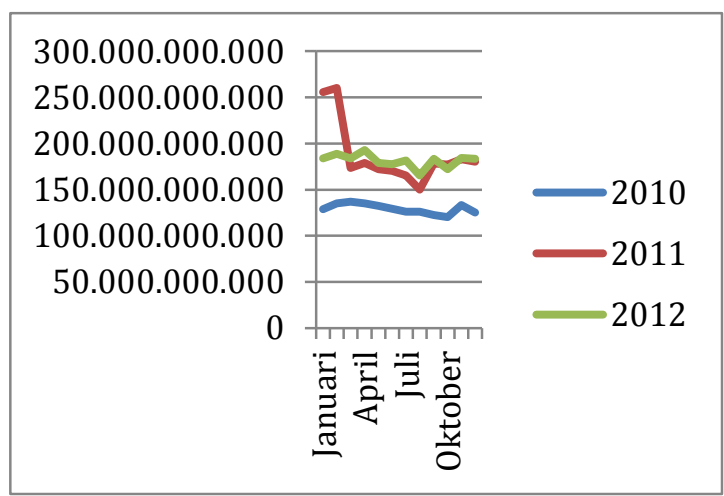

Fig. 3. Capital Growth at YBWSA period 2010 - 2012

Source: YBWSA Financial Report period 2010 - 2012

Figure 3 above shows that the capital used to make waqf assets more productive at YBWSA in 2010-2012 tended to be stable. Capital fluctuations only occurred in March of 2011, which decreased significantly by $33 \%$. The amount of capital used by YBWSA was largely influenced by the profits gained from the previous month.

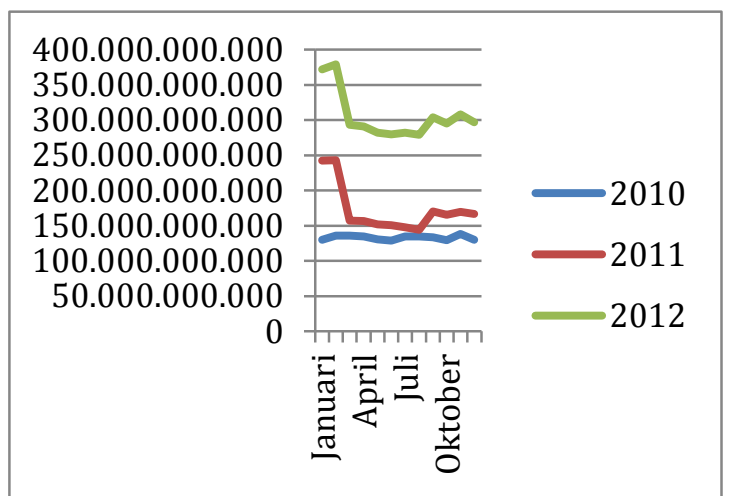

Fig. 4. Waqf Assets Growth at YBWSA period $2010-2012$

Source: YBWSA Financial Report period 2010 - 2012

Figure 4 shows that the rise of waqf assets at YBWSA increased from year to year. In 2011, the number of waqf assets reached 242.3 billion in January. The waqf asset value increased by $86 \%$ when compared with the value of waqf assets in January 2010, which amounted to 130 billion. Meanwhile, in 2012, the waqf assets also increased to Rp 372 billion in January, or an increase of 54\% when compared with the value of waqf assets in January 2011.

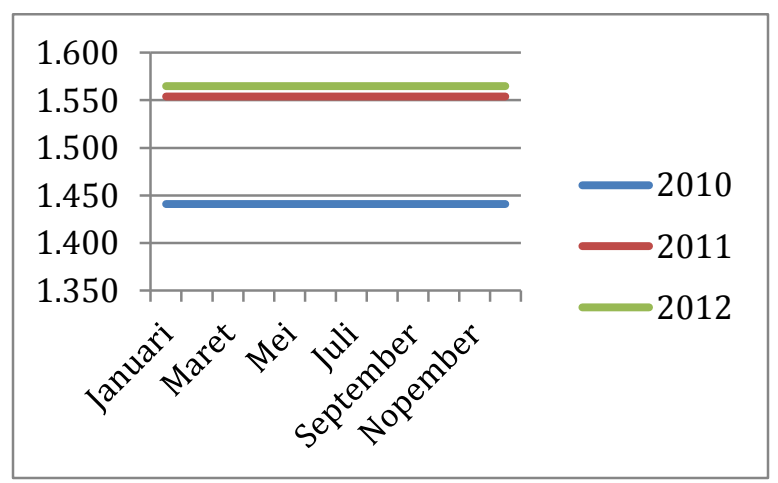

Fig. 5. Labor Growth at YBWSA period $2010-2012$

Source: YBWSA Financial Report period 2010 - 2012

Figure 5 shows the development of labor input (man-hours unit) at YBWSA environment. In this figure, it appears that the number of workers who are in the scope of YBWSA and the whole unit activity has increased every year. In 2010, total employment at YBWSA amounted to 1,441 persons. This number increased in 2011 to 1,554 persons and, in 2012 increased to 1,565 persons. Increased employment at YBWSA occurs cyclically every year and not every month. That is because the recruitment at YBWSA is held once a year, so that the number of workers in each month is likely to remain.

Based on the results of statistical testing with SPSS 18 software, there are some things that can be inferred: 
1. Regression equation form of capital is as follows:

$\operatorname{Ln} Y=40.409+1.534 \operatorname{Ln}$ Modal $-5.024 \operatorname{Ln} T K+0.178 \operatorname{Ln} A W$

Therefore, the equation of Cobb-Douglas production function of YBWSA based on the regression calculations above is as follows:

$Y=354.328 .200 .999 .387 .000 \times K^{1.534} \times L^{-5.024} \times A W^{0.178}$

2. The three input variables have different properties to the revenue of YBWSA, with the details as follows:

a. Capital variable has a value of input elasticity 1.534, which is greater than 1. This means that the capital increase by 1 unit will increase the output of revenue with an increase greater than 1 unit.

b. Labor variable has a value of input elasticity -5.024, which is smaller than 1 and negative. That is, the addition of 1 unit of labor will reduce the output of revenue so that it becomes smaller than 1 unit.

c. Waqf assets variable has a value of input elasticity 0.178 , which is greater than 1 . This means that the capital increase by 1 unit will increase the output of small income of 1 unit.

3. Capital, labor and waqf asset variable, either simultaneously or partially, do not significantly affect the earnings of YBWSA. Consequently, YBWSA can generate income even though there is no labor, capital and waqf assets.

4. The number of coefficients of all independent variables, namely labor, capital and waqf assets, will generate a value of -3.31 . The overall value of the coefficient is less than 1 . The results of these calculations show that the management of waqf assets in YBWSA, viewed from the perspective of the production function, is classified as Decreased Return to Scale. That is, the addition of the input would reduce the output, so that it can be concluded that the management of waqf assets in YBWSA is relatively inefficient.

5. The coefficient of determination in the regression model amount to only 0.138 . That is, only $13.8 \%$ determinants of the YBWSA revenue that can be explained by the model, while $86.2 \%$ is influenced by factors outside the model.

From the findings above, we found that CobbDouglas is not suitable in analyzing YBWSA management. In this case, there is a suspect cause of insignificant valuation from the Cobb-Douglas formula, which is caused by the YBWSA main core units, which are education (schools and university) and healthcare (hospital) units, which are considered as non-profit sector that do not produce a visible input. Another possible reason is YBWSA revenues from these main units' business cycle affect YBWSA revenues. For example, YBWSA gains high revenues from schools and universities at the beginning of the academic year due to new students' payment, while, in other months, YBWSA will not receive the same amount of revenue because, in universities, students only pay once in a semester, while, in schools, they pay monthly payments of a lesser amount. This contributed to the insignificant result of statistical calculation.

Despite the insignificant result, we can see here that the most influential factor to increase YBWSA productivity is capital. Capital has elasticity score of 1.534 , which means that additional capital input of 1 unit will contribute to additional output of 1.534 unit. In other words, capital accumulation will enhance the growth of YBWSA at a higher rate than their investment in capital accumulation. On the other hand, labor variable can be considered as a production factor that should be maintained carefully. Labor variable elasticity score at -5.024 means that 1 unit of additional labor input will decrease output by 5.024 units. YBWSA should evaluate the performance of their labor in order to enhance their development in the future.

\section{CONCLUSION AND RECOMMENDATION}

YBWSA as an economic unit that manages waqf is considered not yet efficient. Cobb-Douglas based regression calculation resulted that YBWSA is not efficient due to their labor performance. On the other hand, capital variable is a good variable to be developed in the future due to positive elasticity. Therefore, in the following years, YBWSA should focus on capital accumulation and labor's performance evaluation in order to better develop their waqf management. However, due to this study's insignificant result, future research in this issue should be conducted using a better method that is able to comprehensively cover all aspects of waqf management, particularly inside YBWSA management with their non-profit nature. 


\section{REFERENCES}

[1] Al-Haritsi, DR. Jaribah bin Ahmad. 2006. Fikih Ekonomi Umar bin Al-Khathab. Jakarta: Khalifah.

[2] Al-Kabisi, Muhammad Abid Abdullah. 2004. Hukum Wakaf : Kajian Kontemporer Pertama dan Terlengkap tentang Fungsi dan Pengelolaan Wakaf serta Penyelesaiannya atas Sengketa Wakaf. Depok : IIMan Press.

[3] Arifin, Zainul. 2015. Pertumbuhan Aset Wakaf dan Dilema Produktifitas. Jurnal Bimas Islam Vol. 8 No. IV tahun 2015: 659-684. Jakarta: Direktorat Pemberdayaan Wakaf Direktorat Jenderal Bimbingan Masyarakat Islam.

[4] Berber, P., et al (2011). Efficiency in fundraising and distributions to cause-related social profit enterprises. Socio-Economic Planning Sciences, 45(1), 1-9.

[5] Direktorat Pemberdayaan Wakaf. 2015. Dinamika Perwakafan di Indonesia dan Berbagai Belahan Dunia. Jakarta: Kementerian Agama.

[6] Danardono, Danny Alit. 2008. Pengaruh Wakaf Produktif terhadap Peningkatan Pendapatan Nazhir (Kasus Wakaf di Jakarta). Tesis tidak diterbitkan. Jakarta: Program Studi Kajian Timur Tengah dan Islam Program Pascasarjana Universitas Indonesia.

[7] Fauzia, Amelia. 2008. Faith and the State: a History of Islamic Philanthropy in Indonesia. Disertasi tidak diterbitkan. Melbourne Faculty of Arts University of Melbourne.

[8] Fauzia, Ika Yunia, Abdul kadir Riyadi. 2014. Prinsip Dasar Ekonomi Islam Perspektif Maqashid Al-Syari'ah. Jakarta: Kencana Prenadamedia Group.

[9] Ginting, Rosnani. 2007. Sistem Produksi. Edisi Pertama. Yogyakarta: Graha Ilmu.

[10] Ghozali, Imam. 2005. Aplikasi Analisis Multivariat dengan Program SPSS. Semarang: Badan Penerbit Universitas Diponegoro.

[11] Gujarati, Damodar. 1998. Ekonometrika Dasar. Jakarta: Erlangga.

[12] Hanif, N., \& Arshed, N. (2016). Relationship between School Education and Economic Growth: SAARC Countries. International Journal of Economics and Financial Issues, 6(1).

[13] Hilmi, Hasbulah. 2012. Dinamika Pengelolaan Wakaf Uang: Studi Sosio-Legal Perilaku Pengelolaan Wakaf Uang Pasca Pemberlakuan UU No. 41 Tahun 2004 Tentang Wakaf. Ijtihad, Jurnal Wacana Hukum Islam dan Kemanusiaan, Vol. 12, No. 2, Desember 2012: 123-143. Pasuruan: STAI Darul Lughah Wadda'wah Bangil.

[14] Huang, W. T., \& Chen, Y. W. (2013). Qualitative data envelopment analysis by affinity set: a survey of subjective opinions for NPOs. Quality \& Quantity, 1-15.

[15] Huda, N., et al. (2017). Problems, Solutions and Strategies Priority for Waqf in Indonesia. Journal of Economic Cooperation \& Development, 38(1), 29.

[16] Ishom, Muhammad. 2014. Efektivitas Undangundang No. 41 Tahun 2004 tentang Pengaturan Wakaf Produktif. Jurnal Bimas Islam, Vol. 7 No. 4: 663-698. Jakarta: Direktorat Pemberdayaan Wakaf Direktorat Jenderal Bimbingan Masyarakat Islam.

[17] Hidayat, Mohamad. 2010. An Introduction to The Sharia Economic: Pengantar Ekonomi Syariah. Jakarta: Zikrul.

[18] Kahf, Mundzir. 2005. Manajemen Wakaf Produktif. Jakarta: Khalifa.

[19] M. Nazir. 2005. Metodologi Penelitian. Bogor : Ghalia Indonesia.

[20] Mankiw, N. Gregory. 2001. Principles of Economics Second Edition. USA: Harcourt College Publisher.

[21] Mannan, Muhammad Abdul. 1995. Teori Dan Praktek Ekonomi Islam. Yogyakarta: Dana Bakti Wakaf.

[22] Martínez Franco, C. M., \& Guzmán Raja, I. (2016). Programme efficiency analysis in Spanish foundation sector. Spanish Journal of Finance and Accounting/Revista Española de Financiación y Contabilidad, 1-22.

[23] Mehrabani, F., et al. 2016. Examining the effects of doing business on Iran and MENA countries' economic growth. International Journal of Islamic and Middle Eastern Finance and Management, 9(1), 2-23.

[24] Muhammad. 2004. Ekonomi Mikro Dalam Perspektif Islam. Yogyakarta: BPFEYogyakarta.

[25] Nasution, Mustofa Edwin. 2006. Pengenalan Eksklusif Ekonomi Islam. Jakarta : Kencana.

[26] Pindyck, Robert S dan Rubinfeld, Daniel L. 2007. MIKROEKONOMI, Edisi Keenam Jilid 1. Jakarta: PT. Indeks.

[27] Ritchie, William J. and Kolodinsky, Robert W. 2003. "Nonprofit Organization Financial Performance Measurement-An Evaluation of New and Existing Financial Performance Measures." Nonprofit Management \& Leadership, 13 (4): 367-381.

[28] Soekartawi. 1990. Teori Ekonomi Produksi: Dengan Pokok Bahasan Analisis Fungsi CobbDouglas. Jakarta: PT. Raja Grafindo Persada.

[29] Sukmadinata. 2006. Metode Penelitian Pendidikan. Bandung: Remaja Rosdakarya. 